Customer satisfaction and competitiveness in the Chinese E-retailing: Structural

Equation Modeling (SEM) approach to identify the role of quality factors

\author{
Nachiappan Subramanian* \\ Nottingham University Business School China, \\ The University of Nottingham Ningbo China, \\ 199 Taikang East Road, Ningbo, 315100. \\ nachiappan.subramanian@nottingham.edu.cn \\ Phone: +8657488180197 \\ Angappa Gunasekaran \\ Department of Decision and Information Sciences, \\ Charlton College of Business, \\ University of Massachusetts - Dartmouth, \\ 285 Old Westport Road, North Dartmouth, MA 02747-2300, USA \\ E-mail: agunasekaran@umassd.edu
}

Jie YU

Nottingham University Business School China, The University of Nottingham Ningbo China,

199 Taikang East Road, Ningbo, 315100.

Jie.Yu@nottingham.edu.cn

Phone: +8657488180360

\title{
Jiang Cheng
}

Nottingham University Business School China, The University of Nottingham Ningbo China, 199 Taikang East Road, Ningbo, 315100. zx08157@nottingham.edu.cn

\section{Kun Ning}

Nottingham University Business School China, The University of Nottingham Ningbo China, 199 Taikang East Road, Ningbo, 315100.

Karen.Ning@nottingham.edu.cn

Phone: +8657488180558

* Corresponding Author 


\title{
Customer satisfaction and competitiveness in the Chinese E-retailing: Structural Equation Modeling (SEM) approach to identify the role of quality factors
}

\begin{abstract}
This paper attempts to study the impact of customer satisfaction and the Chinese e-retailers competitiveness using quality factors. Two conceptual models have been proposed to analyze the impact of Chinese customer satisfaction and competitiveness. Using empirical survey from young population who use quite extensively online purchase, this study, with the support of Structural Equation Modeling (SEM) identifies the importance of reliability in service quality and purchasing experience in e-service quality as dominant customer satisfaction factors. Furthermore, this study suggests that Chinese e-retailers to be competitive have to focus more on logistics and delivery of products compared to other intangible service quality factors. The outcome of the study would be highly beneficial to the Chinese electronic retailers to fine tune their strategy to satisfy the growing demand. This study would also guide third party logistics to be more competitive in future. Furthermore, this study can supplement government policy makers to regulate the growing volatile market.
\end{abstract}

Keywords: Customer satisfaction; e-retailing; competitiveness; quality factors

\section{Introduction}

Electronic retailing (e-retailing) is a popular channel for selling goods in China (CNNIC, 2011). Popular e-retailers in China include Taobao Marketplace (Customer-to-Customer electronic platform), T-mall.com (a Business-to-Customer electronic platform), 360buy (Business-to-Customer electronic platform), Amazon.cn (Business-to-Customer electronic platform) and Dangdang.com (Business-to-Customer electronic platform).

A recent report by Goodman Group suggests that the population for online purchasing worldwide is growing at a tremendous rate i.e. $15 \%$ to $20 \%$ per annum (Goodman report, 2012). However the growth rate is highly exponential in China and it is around $75 \%$ per annum. There are 150 million Internet users in China who are spending around USD 200 to USD 250 per year. The e-retailing market worth is going to be USD 305 billion during 2015 . 
Collier and Bienstock (2003) pointed out that e-retailing is not only selling the product through online but also offering service which is considered to be vital process and it contains both tangible and intangible aspects. The quality of the online shopping process has been found to influence customers' purchase decisions, customer satisfaction, logistics selection choice and loyalty to e-retailing (Fassnacht and Koese, 2006). Hence, to keep competitiveness, e-retailers should not only provide superior goods, but also offer "a better purchasing environment, better personalization choice, and greater customer control" and make sure that the online purchase process is convenient and efficient for customers.

Firstly, measuring the quality of electronic service (intangible) is a paramount task for proactive e-retailers in future to satisfy the demanding customers. Scholars have proposed service quality models to measure customer satisfaction in physical service and to the best of our knowledge there are very few studies available to measure customer satisfaction with both electronic service quality (e-service quality) and service quality on buyer perspective and its role to improve competitiveness. Our paper measures customer satisfaction index using American Customer satisfaction Index (ACSI) model. Furthermore, there are few studies specifically addressed the customer satisfaction issues related to e-retailing in China.

On the other hand from competitive point of view, the other predominant aspect which plays a vital role in the e-service process is how the e-retailers are able to deliver their products to the customers (tangible service). Third party logistics service providers are the important driver in this aspect (Liu et al, 2008). In famous Chinese e-retailors, customers can choose a particular third party logistics provider from a wide range of choices. Thus, measuring the service quality of third party logistics service providers is measuring the service quality of eretailing in China. Hence, our contributions in this paper are to address the following research objectives:

- To capture customer satisfaction in the Chinese e-retailing.

- To develop a structural equation model with quality factors (service quality and eservice quality) that have direct or causal relationship with customer satisfaction and competitiveness of the Chinese e-retailers.

- To suggest influencing quality factors and choice of logistics selection that drives the competitiveness of the Chinese e-retailers.

This paper is organized as follows Section 2 discusses factors governing e-retailing with respect to retailer and customer perspectives. Section 3 narrates the customer satisfaction 
index in general and the Chinese context in particular. Section 4 summarizes the studies that relate customer satisfaction with quality factors. Section 5 proposes two conceptual models to understand the role of quality factors in customer satisfaction and e-retailer competitiveness. Section 6 delineates structural equation modeling approach used in the current context under research methodology. Section 7 discusses the major findings of this study. Finally section 8 summarizes major outcome, limitations and future scope in conclusion section.

\section{E-retailing}

E-retailing made the young generation passionate because they feel the benefits such as convenience, time saving, a good deal of product information, door to door services and 247 services (Liu et al, 2008). The online purchase process involves three stages which are presales stage, online sales stage and post-sales stage. Both customer and e-retailers would have different roles and objectives at different stages. In the pre-sales stage, e-retailers attempt to attract consumers by offering economical products with great service while customers have to make a decision to choose a particular e-retailer. During the online sales stage, customers would do online purchasing with e-retailers providing ease of use and security. In the postsales phase, e-retailers have to deliver the products safely and to support customers if there are any issues or problems with respect to products (Bames and Vidgen, 2002).

\subsection{E-retailers competing factors}

High quality service at a low price, fast delivery of goods combined with enhanced website performance retains customers in e-retailing (Shankar et al, 2003). In addition to these factors, Jarvenpaa and Todd (1997) in their study have reported a few more factors which capture customer attitudes and shopping intention. These factors include product characteristics (such as variety, quality and price), shopping experience (such as effective, convenience and pleasure), customer service (such as responsiveness, assurance, reliability, tangibility and intangibility), and consumer risks (such as social risk, economic risk, performance risk, privacy risk and policy risk). Meanwhile, Lohse and Spiller (1998) endorsed that e-retailers to be successful should focus on goods they sell (such as quantity of products, goods variety, products' quality, and price of goods),e-service (including frequently asked questions - FAQs, e-retailers' credit and after sale service), marketing promotion (such as sales performance, advertising investment and special promotions),shopping convenience (such as stores' management and arrangement), checkout method (such as availability of e- 
payment methods and ease of e-payment moment) and e-retailers' websites navigation (such as ease of use e-menus and search guidance) as the key features. Few emphasized the importance of the Internet specifically on service quality, system quality, information quality, learning capability, playfulness, and system use and marketing (Liu and Arnett, 1999; Zhang, 2006).

\subsection{Customer attractive factors}

From customers' perspective, e-retailer' reputation, other customers' comments or feedbacks and pre- and post-sales services are three major elements which predict the level of security and reliability of the online purchasing process (Szymanski and Hise, 2000). As a very important part in e-retailing, e-retailer' level of service quality directly affects consumer online purchasing behaviors, such as e-retailer selection and e-loyalty. Lee and Lim (2005) reported that shopping online is a complex process and it includes web navigation, searching for information, information transactions, delivery, customer interaction, checkout, and so on. However, it is difficult for customers to evaluate the details of each independent process. They are only able to perceive from the consequences of the overall service (Riel et al., 2001). In general, the experience of purchasing online include the online consumers' general emotional responses and sensation for acting with their whole online shopping process, and will finally influence online customers' purchasing decision making. Effecting online purchasing decisions include performance and reputation of e-retailers, pre- and post-sales services, other buyers' evidence or feedbacks, delivery speed, quality and price of products, brand building (Koufaris, 2002).

Szmanski and Hise (2000) point out that the e-satisfaction as the result of online customers' perceptions of online purchasing process includes online shopping time and ease of browsing, marketing promotion with regard to product, quantity and quality information of products; website design which refers to clean screens, ease of search paths and clear introductions; and financial security. In addition, e-retailer image is another serious element in the customer purchasing decision making process (Nevin and Houston, 1980). While, under an ecommerce environment, the features of electronic retailers (e-retailers) image is quite different with the characteristics of a real retail store image (Jahng et al, 2000). Many research studies have been carried out to understand the characteristics of web-based eretailing system, besides environment of physical retail store, level of service quality, and quality of goods. Liu et al. (2000) identified the key factor of e-retailing image is website design. In their study, they found that a well-designed website would attract much more 
regular customers and make customers a positive attitude toward the e-retailers and their products and service. The study by Imrie et al. (2002) show that quality of e-service quality can bring positive benefits, such as customer retention and market growth.

Overall e-retailers aim to enhance customer satisfaction and loyalty to their stores by offering competitive advantages, such as a well-design and ease of use website, convenience purchasing, variety of product information, speedy delivery and competitive pricing (Verhoef \& Langerak, 2001). Electronic retailers believe customer satisfaction always brings great results such as customer retention, positive word of mouth, and increased profit (Zeithaml et al., 2002). Thus, it is important for electronic retailers, to meet customer requirements and to make effort in each aspect in effecting customer satisfaction in the B2C e-commerce (Buzzell $\&$ Gale, 1987). Furthermore, many scholars agree that total service quality of electronic retailers is essential to customer satisfaction (Janda et al., 2002). However, there is very limited empirical research of customer satisfaction and e-service quality in e-retailing in the context of China.

\section{Customer satisfaction index}

Oliver (1980) defined the customer satisfaction as customers' evaluations of a product or service with regard to their needs and expectations. Marketing researchers have paid more attention towards measurement of service quality to understand customer satisfaction. Both researchers and practitioners give more weightage to customer satisfaction, because, a high degree of customer satisfaction can lead to customer retention and enhance companies' market share (Yuksel and Yuksel, 2002).In essence, e-retailing companies' managers need to know how to treat customer and to understand which factors (both tangible and intangible) affect customer satisfaction towards e-service quality and finally willing to return to purchase from their company (Hansemark and Albinsson, 2004).Satisfaction is an emotional reaction to the difference between what customer's expectation and what they receive (Zineldin, 2000). In e-retailing commerce, Anderson and Srinivasan (2003) describe electronic satisfaction as "the contentment of the customer with respect to his or her prior purchasing experience with a given electronic commerce firm". Prior researches have also indicated that customer satisfaction leads to customer loyalty (Pont and McQuilken, 2005). In addition to that Gommans et al. (2001) proposed that e-loyalty comprises of brand value, trust and security, website and technology, and customer service. In a highly competitive e-commerce market, electronic retailers need to create great service quality to target customers and oversatisfy them to retain them (Tan and Pawitra, 2001). 


\subsection{Customer satisfaction index}

Garver et al. (2002) argue that to strengthen competitive advantage of companies, e-retailing managers should better understand their customers, and provide highest quality products or effective services. According to market orientation and customer satisfaction researches show that there is a direct relationship between customer satisfaction and e-stores' performance (Anderson and Srinivasan, 2003). Therefore, under the e-retailing commerce environment, Mckinney et al. (2002) point out that online retailers have to know how to satisfy customers, because it will assist them to keep develop and get market share. Many studies proposed different models to measure the degree of customer satisfaction and they are European Customer satisfaction Index (ECSI), Sweden customer satisfaction model index (SCSB), and American customer satisfaction index (ASCI). ASCI model is used quite extensively by researchers

\subsection{Chinese customer satisfaction study}

Kim and Stoel (2004) emphasized that online customers' needs greatest satisfaction during online purchasing process, or else they will switch to another e-retailer. A survey done by CNNIC (2011) reported that only 3.5 percent Chinese online customers are totally satisfied with online shopping process. Customer dissatisfaction will have negative effects and hence Chinese e-retailers have to pay their fullest attention to attract Chinese customers. In general Chinese customers are more sensitive to price during online purchase than quality until now whereas recent studies state that they started to pay attention towards quality than price due to their improved living standards (Lu, 2005). Compared with western countries, China greatly differs in commerce culture, logistic industry and credit building system. Chinese commerce culture contains eastern traditional culture system, and the level of logistics in China is far below than developed countries. However, there is not well building of credit system in China (Gentry, 1982). Previous research identified that in different country context that culture, logistics and credit system are three major factors that decides customer behavior and satisfaction (David, 2007; Sharma et al., 1995; Gentry, 1982).However, very few studies have researched Chinese e-retailing online shopping customer satisfaction. This motivated us to study the influencing tangible and intangible factors of online customer satisfaction and competitiveness of e-retailers. Table 1 summaries various studies carried out to understand the Chinese customer satisfaction. We found only four studies related to e-commerce or online shopping in the Chinese context. However, their focus is towards web quality service and overall analysis of contributing factors. Out of the four studies one study used SEM to 
model the web quality service. To best of our knowledge there is no specific study which takes into account both tangible and intangible aspects to measure e-retailing e-service quality and customer satisfaction. Similarly it's very hard to find the relationship between tangible and intangible factors and its relationship with competitiveness of e-retailer.

Table 1: Chinese customer satisfaction study

\begin{tabular}{|c|c|c|c|c|}
\hline S.No & Source & Industry & Aim of study & Methodology \\
\hline 1 & $\begin{array}{l}\text { Liu et al. } \\
\text { (2008) }\end{array}$ & $\begin{array}{l}\text { e- } \\
\text { commer } \\
\text { ce }\end{array}$ & $\begin{array}{l}\text { Present a model of customer satisfaction index(CSI) } \\
\text { in e-commerce using fuzzy techniques and provide } \\
\text { a method for calculating CSI }\end{array}$ & fuzzy model \\
\hline 2 & $\begin{array}{l}\text { Geng and } \\
\text { Chu } \\
(2012)\end{array}$ & $\begin{array}{l}\text { Manufa } \\
\text { cturing }\end{array}$ & $\begin{array}{l}\text { Evaluation customer satisfaction by PSS (product- } \\
\text { service system) design }\end{array}$ & $\begin{array}{l}\text { IPA } \\
\text { (Importance- } \\
\text { performance } \\
\text { analysis), } \\
\text { Kano Model, } \\
\text { DEMATEL }\end{array}$ \\
\hline 3 & $\begin{array}{l}\text { Kuo } \\
(2011)\end{array}$ & Airline & $\begin{array}{l}\text { Combining VIKOR, GRA, and interval-valued } \\
\text { fuzzy sets to evaluate service quality of Chinese } \\
\text { cross-strait passenger airlines via customer surveys }\end{array}$ & SERVQUAL \\
\hline 4 & $\begin{array}{l}\text { Liu et al. } \\
\text { (2008) }\end{array}$ & $\begin{array}{l}\text { Online } \\
\text { shoppin } \\
\mathrm{g}\end{array}$ & $\begin{array}{l}\text { The overall Customers' satisfaction will be } \\
\text { influence by some elements in three online } \\
\text { purchasing process: information search and } \\
\text { alternative evaluation stage, purchase stage and } \\
\text { post-purchase stage.(delivery part has the greatest } \\
\text { effect on satisfaction) }\end{array}$ & $\begin{array}{l}\text { survey (field } \\
\text { work, online, } \\
\text { e-mail); } \\
\text { SPSS } \\
\text { regression } \\
\text { analysis }\end{array}$ \\
\hline 5 & $\begin{array}{l}\text { Sheng and } \\
\text { Liu } \\
(2010)\end{array}$ & $\begin{array}{l}\text { Online } \\
\text { shoppin } \\
\mathrm{g}\end{array}$ & $\begin{array}{l}\text { Using four dimensions of e-service quality: } \\
\text { efficiency, requirement fulfillment, accessibility } \\
\text { and privacy to analyze satisfaction and loyalty }\end{array}$ & $\begin{array}{l}\text { Parasuraman } \\
\text { et al.'s (2005) } \\
\text { E-S-QUAL } \\
\text { scale }\end{array}$ \\
\hline 6 & $\begin{array}{l}\text { Yoon } \\
(2010)\end{array}$ & $\begin{array}{l}\text { Online } \\
\text { banking }\end{array}$ & $\begin{array}{l}\text { Study on the six antecedents of customer } \\
\text { satisfaction- ease of use, design, speed, security, } \\
\text { information content and customer support service }\end{array}$ & $\begin{array}{l}\text { a structural } \\
\text { multi-group } \\
\text { (a high- } \\
\text { experience } \\
\text { group and a } \\
\text { low- } \\
\text { experience } \\
\text { group) }\end{array}$ \\
\hline 7 & $\begin{array}{l}\text { Zhao et } \\
\text { al. }(2012)\end{array}$ & $\begin{array}{l}\text { Mobile } \\
\text { services }\end{array}$ & $\begin{array}{l}\text { Explore the three dimensions of service quality } \\
\text { (interaction quality, environment quality and } \\
\text { outcome quality)whether have significant and } \\
\text { positive effects on transaction-specific satisfaction } \\
\text { and cumulative satisfaction }\end{array}$ & empirical test \\
\hline 8 & $\begin{array}{l}\text { Chiu et al. } \\
\text { (2011) }\end{array}$ & $\begin{array}{l}\text { Automo } \\
\text { bile }\end{array}$ & $\begin{array}{l}\text { Research Taiwan's customer satisfaction index to } \\
\text { find the largest benefit indexes for the influence of } \\
\text { satisfaction }\end{array}$ & TCSI model \\
\hline 9 & $\begin{array}{l}\text { Song and } \\
\text { Yan } \\
(2006)\end{array}$ & Housing & $\begin{array}{l}\text { Analyze the HIS of low-priced housing in Beijing } \\
\text { to enhance the quality of homes and promote the } \\
\text { housing market and improve the standard of living } \\
\text { for lower income people and provide suggestions to } \\
\text { policy makers }\end{array}$ & $\begin{array}{l}\text { HIS and } \\
\text { ACSI model }\end{array}$ \\
\hline
\end{tabular}




\begin{tabular}{|c|c|c|c|c|}
\hline 10 & $\begin{array}{l}\text { Liu et al. } \\
(2006)\end{array}$ & $\begin{array}{l}\text { Express } \\
\text { delivery }\end{array}$ & $\begin{array}{l}\text { Discuss from discrepancy index, endurance index, } \\
\text { complaint index and recognition index to measure } \\
\text { of express mail service }\end{array}$ & \\
\hline 11 & $\begin{array}{l}\text { Kim et al. } \\
(2006)\end{array}$ & $\begin{array}{l}\text { Online } \\
\text { hotel } \\
\text { reservati } \\
\text { on }\end{array}$ & $\begin{array}{l}\text { Identify the determinants affecting Chinese hotel } \\
\text { customers' online booking satisfactions, from } \\
\text { information needs, service performance and } \\
\text { reputation, convenience, price benefits, } \\
\text { technological inclination and safety }\end{array}$ & $\begin{array}{l}\text { factor } \\
\text { analysis }\end{array}$ \\
\hline 12 & $\begin{array}{l}\text { Yang and } \\
\text { Peng } \\
(2008)\end{array}$ & $\begin{array}{l}\text { Constru } \\
\text { ction } \\
\text { project }\end{array}$ & $\begin{array}{l}\text { Evaluation of PCM service satisfaction index from } \\
\text { in service and post-service }\end{array}$ & \\
\hline 13 & $\begin{array}{l}\text { Chang } \\
\text { and } \\
\text { Chang } \\
(2010)\end{array}$ & $\begin{array}{l}\text { Airline } \\
\text { service }\end{array}$ & $\begin{array}{l}\text { Investigates the relationships among service } \\
\text { recovery, recovery satisfaction, overall customer } \\
\text { satisfaction, and customer loyalty in airline services }\end{array}$ & $\begin{array}{l}\text { Structural } \\
\text { equation } \\
\text { models }\end{array}$ \\
\hline 14 & $\begin{array}{l}\text { Wu and } \\
\text { Liang } \\
(2009)\end{array}$ & $\begin{array}{l}\text { Luxury- } \\
\text { hotel } \\
\text { restaura } \\
\text { nt }\end{array}$ & $\begin{array}{l}\text { Indicated that restaurant environmental factors and } \\
\text { interactions with service employees and other } \\
\text { consumers positively influence customer } \\
\text { satisfaction }\end{array}$ & $\begin{array}{l}\text { Structural } \\
\text { model } \\
\text { analysis }\end{array}$ \\
\hline 15 & $\begin{array}{l}\text { Kuo et al. } \\
\text { (2011) }\end{array}$ & $\begin{array}{l}\text { Condom } \\
\text { inium } \\
\text { manage } \\
\text { ment } \\
\text { services }\end{array}$ & $\begin{array}{l}\text { Analysis service team competence and service } \\
\text { performance reliability to increasing resident } \\
\text { satisfaction }\end{array}$ & SERVQUAL \\
\hline 16 & $\begin{array}{l}\text { Wang et } \\
\text { al. }(2009)\end{array}$ & Tourism & $\begin{array}{l}\text { Presents a tourist satisfaction model for the } \\
\text { antecedents (tourist expectations, destination image, } \\
\text { perceived quality, and perceived value) and the } \\
\text { consequences (tourist complaints and tourist } \\
\text { loyalty) of tourist satisfaction using Guilin for the } \\
\text { case study }\end{array}$ & $\begin{array}{l}\text { SERVQUAL, } \\
\text { structural } \\
\text { equation } \\
\text { model (SEM) }\end{array}$ \\
\hline 17 & $\begin{array}{l}\text { Lin \& Sun } \\
(2009)\end{array}$ & $\begin{array}{l}\text { Online } \\
\text { shoppin } \\
\mathrm{g}\end{array}$ & $\begin{array}{l}\text { Consider how entrance (technology acceptance } \\
\text { factors, website service quality) affect online } \\
\text { shopping customers' satisfaction }\end{array}$ & $\begin{array}{l}\text { SERVQUAL, } \\
\text { structural } \\
\text { equation } \\
\text { model (SEM) }\end{array}$ \\
\hline 18 & $\begin{array}{l}\text { Song et } \\
\text { al. }(2012)\end{array}$ & Tourism & $\begin{array}{l}\text { Consider about perceived performance, assessed } \\
\text { value and expectations influence tourists' } \\
\text { satisfaction }\end{array}$ & SEM \\
\hline 19 & $\begin{array}{l}\text { Kuo et al. } \\
(2009)\end{array}$ & $\begin{array}{l}\text { Mobile } \\
\text { value- } \\
\text { added } \\
\text { service }\end{array}$ & $\begin{array}{l}\text { Discuss the relationships among service quality, } \\
\text { perceived value, customer satisfaction and post- } \\
\text { purchase intension. }\end{array}$ & $\begin{array}{l}\text { SERVPERF } \\
\text { model }\end{array}$ \\
\hline 20 & $\begin{array}{l}\text { Deng et } \\
\text { al. }(2010)\end{array}$ & $\begin{array}{l}\text { Mobile } \\
\text { instant } \\
\text { message } \\
\text { s (MIM) }\end{array}$ & $\begin{array}{l}\text { Confirm that trust, perceived service quality, } \\
\text { perceived customer value, functional value, } \\
\text { emotional value, contribute to generating customer } \\
\text { satisfaction with MIM }\end{array}$ & \\
\hline 21 & $\begin{array}{l}\text { Chen et } \\
\text { al. }(2011)\end{array}$ & $\begin{array}{l}\text { Home } \\
\text { delivery }\end{array}$ & $\begin{array}{l}\text { Investigate the categorization of home delivery } \\
\text { quality elements derived from service convinces } \\
\text { model and impact on customer satisfaction }\end{array}$ & Kano model \\
\hline
\end{tabular}




\begin{tabular}{|l|l|l|l|l|}
22 & $\begin{array}{l}\text { Wu and } \\
\text { Wang } \\
(2011)\end{array}$ & 3PL & $\begin{array}{l}\text { Analyze the 3PL enterprise customer satisfaction } \\
\text { evaluation method based on soft sets }\end{array}$ & Soft sets \\
\hline
\end{tabular}

\section{Electronic service quality and customer satisfaction}

Service quality is usually expressed as a function of customers' expectations of the service to be provided (based upon their previous experience, the organizations image, the price of the service) compared to their perceptions of the real service experience (Gronroos, 1984; Berry et al., 1985; Johnston and Heineke, 1998). Parasuraman et al. (1988) state the concept of perceptions is the consumer's judgment of the service provider's performance. However, the service performance gap between the introduction of service and the real delivery is bigger than past experience (Chenet et al., 2000). The SERVQUAL model is often used to measure service quality. It contains five dimensions, which are tangibles, reliability, responsiveness, assurance, and empathy (Parasuraman et al., 1994). Structural equation models (SEM) are also used to analyze relationships among variables in marketing and consumer research (Bollen, 1989; Schumacker and Lomax, 1996; Batista- Foguet and Coenders, 2000). A study by Bureau of transport and communications economics stated that the empirical studies are essential to understand e-service quality and its importance among young generation (Bureau of transport and communications economics, 1994). Chang and Yeh (2002) stated that it's hard to describe and measure e-service quality in e-retailing because of its heterogeneity, intangibility, and inseparability. Previous studies on service quality related to the internet suggested that large amount of time frame is needed to measure the interaction of the online customers and the website design but have ignored the e-service quality which is more important than just the reaction of a consumer to website (Yoo and Donthu, 2001). Meanwhile, they also miss other factors such as outcome quality and recovery. These two have much affection on perceptions of quality of online purchasing (Pakdil and Harwood, 2005).

Long back, a study by Kuei (1998) recognized the importance of e-service quality as an important factor for e-retailers sustainable competitive advantage. A recent study of online shopping failures reported that consumers considered the problem in delivery service as the most frequently happening problem in online purchasing process (Liu et al., 2008). On the one hand, consumers cared about web site interactivity (it is easy for them to one click away to switch to another e-retailing company.); on the other hand, they concerned about desired product or service quality. In addition to that, Holloway and Beatty (2003) found that majority of consumers were dissatisfied with delivery speed and complaint solving attitudes, 
and this dissatisfaction affected intentions to return to an e-retailing company.

One of the first and most widely used instruments (SERVQUAL Model) to measure service quality was developed by Parasuraman et al. (1988). Later it has been extended to measure eservice quality (e-SQ). Zeithamal et al. (2002) found that ease of navigation, flexibility, efficiency and security to be added in addition to SERVQUAL model to measure e-service quality. Table 2 shows the indicators of e-SQ. Zeithaml et al. (2002) suggested 11 dimensions to measure e-SQ. However, it has been refined later to six and they are efficiency, system availability, fulfillment, privacy, compensation and contact (Parasuraman et al., 2005). Gefen (2002) categorized e-service quality dimensions into tangibles; a combined dimension of responsiveness, reliability and assurance; and empathy. Furthermore, Li et al. (2002) detailed the dimensions of e-service quality as reliability, responsiveness, integration of communication, assurance and quality of communication. Wolfinbarger and Gilly (2003) proposed an e-SQ scale initially referred as .comQ, which has been modified later to eTailQ.

Table 2: Dimensions of e-Service Quality

\begin{tabular}{|c|c|}
\hline Sources & Dimensions of E-Service Quality \\
\hline Janda et al. (2002) & Performance, security, sensation, information \\
\hline Gefen, (2002) & Tangible, Combine Responsiveness, reliability and assurance, Empathy \\
\hline $\begin{array}{l}\text { Wolfinbarger \& } \\
\text { Gilly (2003) }\end{array}$ & $\begin{array}{l}\text { Web site design, processing speed, aesthetic design, interactive } \\
\text { responsiveness, tangibles }\end{array}$ \\
\hline $\begin{array}{l}\text { Collier \& } \\
\text { Bienstock, (2003) }\end{array}$ & $\begin{array}{l}\text { Process quality (privacy, design, information accuracy, ease of use, } \\
\text { functionality), } \\
\text { Outcome quality (order timeliness, order accuracy, order condition), } \\
\text { Recovery quality (interactive fairness, procedural fairness, outcome } \\
\text { fairness) }\end{array}$ \\
\hline Li et al. (2002) & $\begin{array}{l}\text { Reliability, Responsiveness, Integration of communication, Assurance, } \\
\text { Quality of information, Empathy }\end{array}$ \\
\hline $\begin{array}{l}\text { Parasuraman et al. } \\
2005\end{array}$ & $\begin{array}{l}\text { e-S-QUAL and e-Recs-QUAL (Efficiency, system availability, } \\
\text { fulfillment, privacy, compensation, contact) }\end{array}$ \\
\hline Liu et al. (2008) & $\begin{array}{l}\text { Information search, purchase stage, post-purchase stage, alternative } \\
\text { evaluation stage }\end{array}$ \\
\hline $\begin{array}{l}\text { Sheng \& Liu, } \\
(2010)\end{array}$ & Efficiency, requirement, fulfillment, accessibility and privacy \\
\hline
\end{tabular}

Based on the above it is evident that dimensions of e-SQ contains both service quality and eservice quality factors and the following sections in detail about the details of both quality and e-service quality factors.

\section{1 e-Service Quality factors}

A review of related literature revealed various studies aimed at identifying determinant 
factors of customer satisfaction in electronic commerce B2C and which also conclude that tangibility affects the perceived quality of virtual supply, thus stressing its academic and professional importance. After the review of previous works, it observed that, in generic terms, design refers to usability (ease of navigation), aesthetic aspects of the web site, and page download speed. However, there is a certain overlap between design, reliability of the service and web site content. Few other e-service quality factors are personalization option, customer loyalty, customer control, and purchasing experience (Yoo \& Donthu, 2001; Jun et al, 2004; Lee and Lim, 2005). There is no previous study to analyze intangibility aspects such as purchasing experience and customer control with customer satisfaction.

Table 3 e-service quality factors

\begin{tabular}{|l|l|l|}
\hline Source & e-SQ factors & Dimensions \\
\hline $\begin{array}{l}\text { Yoo and Donthu } \\
\text { (2001); Jun et al. }\end{array}$ & $\begin{array}{l}\text { Purchasing } \\
\text { experience }\end{array}$ & $\begin{array}{l}\text { Feel about purchasing products, product } \\
\text { introduction search goods, information to } \\
\text { compare e-retailers, sellers attitude, delivery } \\
\text { services. }\end{array}$ \\
\hline $\begin{array}{l}\text { Jun et al. (2004); } \\
\text { Lee and Lim (2005) }\end{array}$ & Customer control & $\begin{array}{l}\text { Customer experience about preferred e-retailers } \\
\text { website, complaints re-address mechanism, } \\
\text { contact information with customer service } \\
\text { centre }\end{array}$ \\
\hline
\end{tabular}

\subsection{Service Quality factors}

The main feature distinguishes services from goods is intangibility aspect: services are subjects, and products are objects. Thus, e-retailing companies' image and credit will affect online customers' satisfaction degree (Fizsimons and Fizsimons, 2001). Thus, few have stressed more to reliability and responsiveness of e-retailers as an important aspect than others (Long and McMellon, 2004; Parasuraman et al., 2005). Table 4 describe the usage of the two important factors among the other SERVQUAL factors that include reliability, responsiveness, assurance and empathy factors to measure the service quality.

Table 4: Service quality factors

\begin{tabular}{|l|l|l|}
\hline Source & SQ factors & Dimensions \\
\hline $\begin{array}{l}\text { Chen et al., (2011); } \\
\text { Gong et al., (2012); } \\
\text { Jane, (2011); Lai } \\
\text { et al., (2007). }\end{array}$ & $\begin{array}{l}\text { The evaluation index for emergency logistics system } \\
\text { reliability: timely feedback; sharing; security and } \\
\text { confidentiality; mode and path selection of rationality; } \\
\text { in time of transport arrived; integrity; quick response } \\
\text { ability; coordination control capability; process } \\
\text { standardization; support of advanced technology; } \\
\text { supply capacity; production capacity; fast recovery } \\
\text { ability; availability use; satisfaction; operability; } \\
\text { satisfaction; recoverability; }\end{array}$ \\
\hline
\end{tabular}




\begin{tabular}{|l|l|l|}
\hline $\begin{array}{l}\text { Lai et al., (2007); } \\
\text { Ramezeni et al., } \\
(2012) .\end{array}$ & $\begin{array}{l}\text { Responsive } \\
\text { ness }\end{array}$ & $\begin{array}{l}\text { Mainly refers to the quality of time, from the client to } \\
\text { set the length of time to complete the order; } \\
\text { willingness to help customers and provide promote } \\
\text { service; related service information can easily } \\
\text { obtained; employees can promptly response to your } \\
\text { requests even when they are busy; employees can } \\
\text { promptly serve you. }\end{array}$ \\
\hline
\end{tabular}

\section{Conceptual models}

In previous studies, there are limited researches about customer satisfaction in e-retailing, especially in China. There are few studies about using SERVQUAL to analyze online customer satisfaction on e-service quality in the retailing industry in China. SERVQUAL instrument designed for use in broad set of service business and provides only a basic skeleton through its expectations/perceptions format and can be considered to measure customer satisfaction (Joo and Sohn, 2008). Hence, this study using SERVQUAL basic skeleton investigates the Chinese e-retailing industry's service quality, e-service quality and customer satisfaction.

5.1 SQ and e-SQ on customer satisfaction

Based on ACSI, this paper proposes a new model (Figure 1) to analyze the customer satisfaction of Chinese e-retailing. This study considers the variables of customer expectations, perceived value and customer loyalty in ACSI. According to previous studies, there are few researches about effect of e-service quality and service quality on customer satisfaction. This study relates e-service quality and service quality with aspect customer satisfaction. It also predicts both e-service quality and service quality are positively related to customer satisfaction ( $\mathrm{H} 1$ and $\mathrm{H} 2)$. 


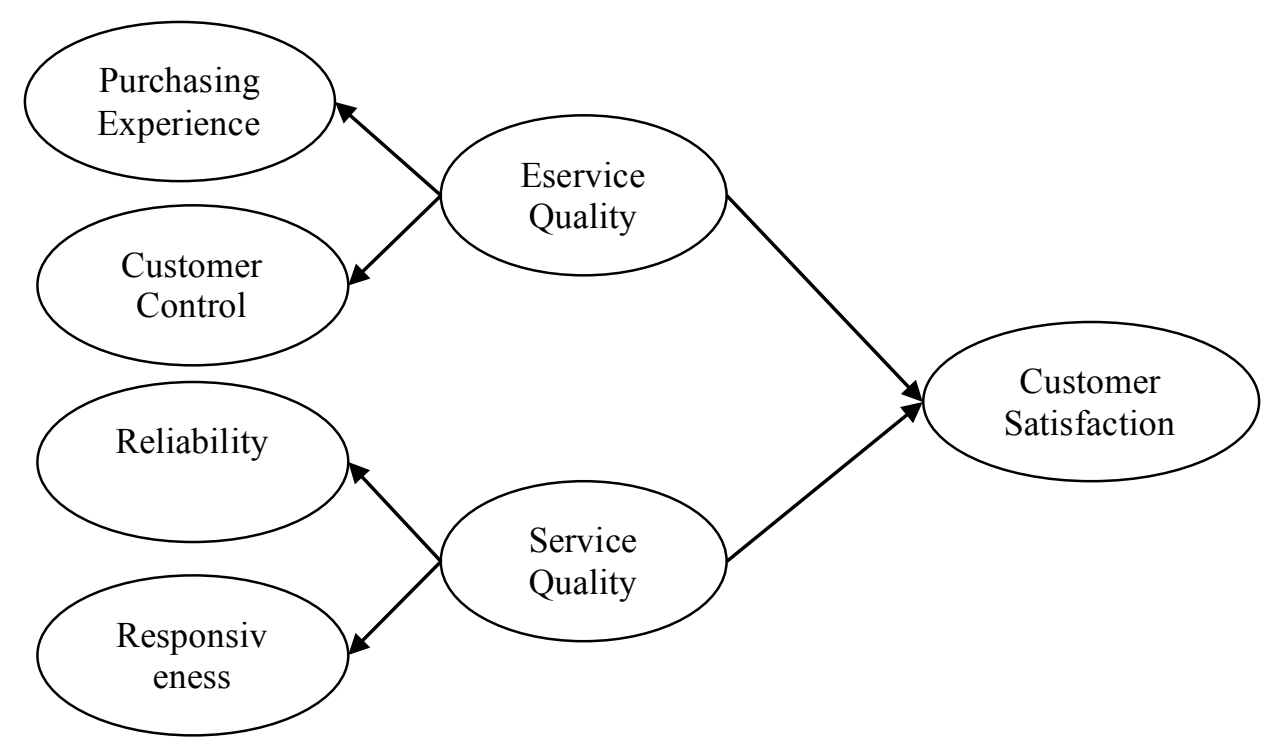

Figure 1: Quality factors on customer satisfaction (Conceptual measurement model)

\section{2 Logistics and quality factors on competitiveness}

The role of the logistics on e-retailers' performance has gained relatively less attention in an e-retailing environment. According to Wang et al. (2008), the significance of logistics service has increased in the e-retailing marketplace. The study of Power et al. (2007) found that logistics capability is positively associated with e-retailers' performance in electronics retailing industry and ensuring customer loyalty.

Langley et al. (2006) stated that Chinese ${ }^{\text {rd }}$ party logistics (3PL) service quality is quite different with $3^{\text {rd }}$ party logistics service quality in developed countries. Goh \& Ling (2003) pointed out that Chinese 3PL service providers take total logistics expenditure as over twice in GDP than many developed countries. In a recent survey, Zhou et al. (2008) established seventy percent of Chinese logistics service providers respondent delivering service declining of Chinese 3PL providers' operational efficiency. The reasons of causing low degree of operational efficiency of Chinese 3PL services providers are: the infrastructures information of technology (IT) and lack of sufficiency transportation, short of service quality, and low awareness of the concept of green logistics. These elements as main barriers to the development of the 3PL service industry in China. However, in many developed countries, it is not a problem in logistics service industries (Wang et al., 2008). The second key difference is the services quality of both west and east $3^{\text {rd }}$ party logistics service providers. There are some researches (Hong \& Liu, 2007; Zhou et al., 2008) established that to compare with 3PL 
service providers in the USA and other developed countries, it shows that China local logistics service providers mainly stress on basic or traditional business such as transportation and warehousing, rather than add value to consumers by offering additional service, high service quality, and integration supply chain. Langley et al. (2006) established that $3^{\text {rd }}$ party logistics users in China consider that the quality of $3^{\text {rd }}$ party logistics service providers' services are more significant than delivery price when they decide to choose a $3^{\text {rd }}$ party logistics service provider.

Thus, to improve online customers' purchasing experience, some electronic retailers, like 360buy, Amazon.cn, and dangdang.com try to build their own logistics systems. The first reason is that especially in rural areas, delivery speed and delivery service quality has been a big problem for the e-retail stores development. Therefore, controlling $3^{\text {rd }}$ party logistic partners' delivery speed and responsiveness is a serious issue (Langley et al., 2006). The second reason is that foreign logistic providers' services are too expensive for both e-retailers and online customers. Wholly-owned delivery companies are found to cover wide areas at speedy delivery, but it cost more financial resources and effort than using $3^{\text {rd }}$ party logistics service. Therefore, later online retailers prefer to cooperate with private $3^{\text {rd }}$ party logistics (3PL) service providers for express to assist with their own delivery services. And online customers would like to choose $3^{\text {rd }}$ party logistics, because it cost less and delivery speed (Hong \& Liu, 2007). In China, the major $3^{\text {rd }}$ party logistics service providers are STO, ZTO, YT, YUNDA, TTK, and SF. The EMS, a local-owned postal service company covers ninety percent of fields of China (EMS, 2009). So, for many rural areas, EMS postal service is used frequently. While, if the place other $3^{\text {rd }}$ party logistic service providers can deliver, people will seldom choosing used EMS, unless to send some official documents. The reason is that: EMS' service is more expensive than other local third party logistics service companies. It is obvious that deliveries to rural place might cause extra charges needs e-retailers or online buyers to pay. Performance of foreign express companies such as FedEx and DHL offer great quality services but that are more expensive than local third party logistics service providers, so it has fewer users than $3^{\text {rd }}$ party logistics service providers in China (Goh \& Ling, 2003). Chinese e-retailers competitiveness depends mostly on options they have for logistics selection (H3) and quality factors (H4) as shown in figure 2. 


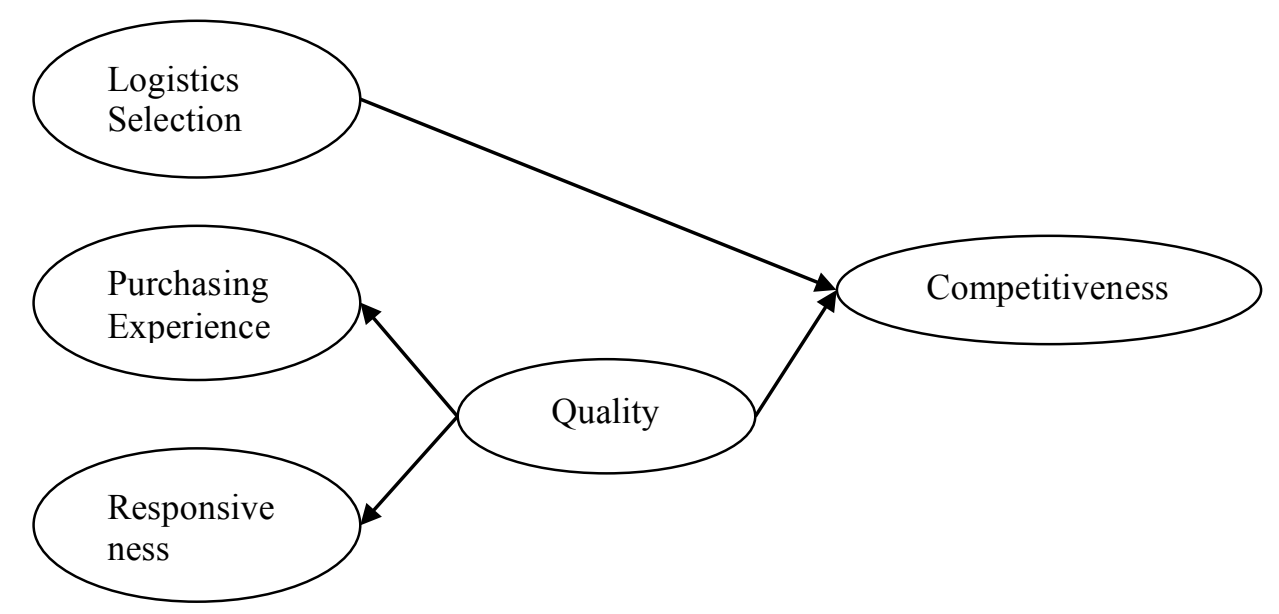

Figure 2: logistics and quality factors on competitiveness (Conceptual measurement model)

\section{Analysis of SEM}

In order to estimate the proposed two SEM models, a questionnaire regarding the measurement variables was distributed in a sino-foreign university in China. This questionnaire contains three parts. Firstly, it captures some general demographic information, such as gender, age, grade, and average monthly expense. Next, the second part measures the five latent constructs for the customer satisfaction model which are customer satisfaction, customer control, purchasing experience, reliability and responsiveness. Finally, the third part measures the additional latent constructs for the competitiveness model which are logistics selection and competitiveness. All items used to measure latent constructs are scored against a scale of 1-to-5, with 5 indicating a complete satisfaction. The specific survey questionnaire is provided in Appendix.

\subsection{Sampling and data collection}

The subjects of questionnaires in this research are the students of a sino-foreign university in China, and they all have a lot of online purchasing experience. The reasons of using university students are that university students are skillful in operating computers and have limited living expenses (Barnes \& Vidgen, 2002). Therefore, most of them are active online shoppers and gain enough online purchasing experience. Consequently, this paper chooses the university students who were from different provinces in China as the targeted subjects to be the representative of online purchasing customers in China. 
We used systematic stratified random sampling technique and sent the questionnaire to 1392 students through various social media, such as QQ groups (similar to MSN and Skype), renren.com (the Chinese version of Facebook), and Weibo (the Chinese version of Twitter. After few weeks, we received 323 feedbacks. Therefore we had a response rate of $23.2 \%$. The response rate is similar to the previous empirical study which has $24.8 \%$ in the Chinese context (Tian, 2010). However, due to the missing data or other errors, we had 162 valid respondents. Table 5 shows the demographic results of these respondents. We had slightly more females than males which is consistent with the gender ratio of the university. Most of respondents are aged between 22-27 and they spend about 1500-2000

Non-response bias was assessed by examining the differences in the mean scores of certain items between firms that responded to the survey and firms that did not. For lack of comparable statistics from non-responding firms, t-tests were used to test the response bias between early and late wave returned surveys, late wave respondents being treated as a proxy for non-respondents (Armstrong and Overton, 1977). In this study, 120 useable responses were received in the early mailing wave and 42 in the late wave. The mean differences between the two groups with respect to the gender, age, grade and average monthly expense were tested using an unpaired t-test. No significant differences were observed at the 0.05 level, indicating no systematic bias between the two groups. These analyses indicate that the study has no major non-response bias problems, and the final sample of 162 firms can be considered as representative of the population.

\subsection{Structural equation modeling approach}

During early nineties Fornell (1992) developed an SEM approach to estimate the ASCI. Later on use of SEM has become popular for customer satisfaction in different domains that include examination of the relationship between flexible IT infrastructure and competitive advantage, network performance on customer satisfaction and loyalty in Korean high speed internet service, IS performance in manufacturing firms and technology commercialization success index (Shin et al., 2009, Kim et al., 2007). Previous study has used SEM to figure out both direct and indirect effects of the casual relationship between factors and customer satisfaction with respect to digital content industry to establish contents specific marketing plans for customer relationship management (Lin, 2007; Joo and Sohn, 2008). Based on its applicability, we use structural equation modeling (SEM) for investigating the two proposed 
research models in Chinese e-retailing. SEM follows a two steps approach constructing the measurement model and testing the structural model (Anderson \& Gerbing 1988). This study employs the SPSS 20 package because it can be used for exploratory factor analysis (EFA) and it includes the Amos 20 for measuring the structural equation models.

\subsubsection{Measurement Model - validity and reliability}

Validity is the extent to which a particular item relates to other items consistent with theoretically derived hypotheses concerning the variables that are being measured (Campbell and Fiske, 1959). In this paper, exploratory factor analysis was conducted to determine the number of constructs and the loadings of items on the corresponding construct. The results of exploratory factor analysis of the two models were shown in Table 5 and Table 6 respectively. It is to test the convergent validity and discriminant validity of latent variables. Convergent validity refers to the degree to which a measure is correlated with other measures that it is theoretically predicted to correlate with. It was assessed by checking loadings to see whether the items measuring the same construct correlate highly among themselves. Discriminant validity describes the degree to which the operationalization does not correlate with other operationalization's that it theoretically should not be correlated with. It was assessed by checking whether the items loaded more strongly on their intended construct rather than other constructs. Furthermore, any item with a factor loading smaller than 0.35 was not considered for further analysis as it did not measure a specific construct (Hair et al., 2006). Based on these criteria, several items were dropped.

Table 5: Exploratory factor analysis for quality factors and customer satisfaction conceptual model

\begin{tabular}{|c|c|c|c|c|c|c|}
\hline Constructs & Variables & Factor loadings & & & & \\
\hline \multirow[t]{3}{*}{ Purchasing experience } & pe1 & 0.836 & & & & \\
\hline & pe2 & 0.861 & & & & \\
\hline & pe3 & 0.595 & & & & \\
\hline \multirow[t]{2}{*}{ Customer control } & $\mathrm{cc} 1$ & & 0.866 & & & \\
\hline & $\operatorname{cc} 2$ & & 0.863 & & & \\
\hline \multirow[t]{3}{*}{ Reliability } & relp1 & & & 0.831 & & \\
\hline & relp2 & & & 0.797 & & \\
\hline & relp3 & & & 0.208 & & \\
\hline \multirow[t]{2}{*}{ Responsiveness } & resp1 & & & & 0.721 & \\
\hline & resp2 & & & & 0.613 & \\
\hline \multirow[t]{3}{*}{ Customer satisfaction } & $\operatorname{cs} 1$ & & & & & 0.852 \\
\hline & $\operatorname{cs} 2$ & & & & & 0.855 \\
\hline & $\operatorname{cs} 3$ & & & & & 0.366 \\
\hline
\end{tabular}


Table 6: Exploratory factor analysis for logistics and quality factors on competitiveness model

\begin{tabular}{|c|c|c|c|c|c|}
\hline Constructs & Variables & Factor loadings & & & \\
\hline \multirow[t]{5}{*}{ Logistics selection } & Ls1 & 0.897 & & & \\
\hline & Ls2 & 0.921 & & & \\
\hline & Ls3 & 0.794 & & & \\
\hline & Ls4 & 0.736 & & & \\
\hline & Ls5 & 0.692 & & & \\
\hline \multirow[t]{4}{*}{ Purchasing experience } & Pe1 & & 0.800 & & \\
\hline & $\mathrm{Pe} 2$ & & 0.821 & & \\
\hline & Pe3 & & 0.773 & & \\
\hline & $\mathrm{Pe} 4$ & & 0.700 & & \\
\hline \multirow[t]{3}{*}{ Reliability } & Rel1 & & & 0.856 & \\
\hline & Rel2 & & & 0.848 & \\
\hline & Rel3 & & & 0.858 & \\
\hline \multirow[t]{4}{*}{ competitiveness } & Com1 & & & & 0.693 \\
\hline & Com2 & & & & 0.660 \\
\hline & Com3 & & & & 0.719 \\
\hline & Com4 & & & & 0.797 \\
\hline
\end{tabular}

Table 7 and 8 shows the correlations between constructs, composite reliability, Cronbach's Alpha and the average variance extracted (AVE) of each construct. AVE is utilized to assess the discriminant validity, the square root of which should be larger than the correlations between constructs (Chin, 1998). The results showed that all items meet the requirement.

The reliability or internal consistency was assessed through Cronbach's alpha coefficient and composite reliability. As suggested by Nunally (1978), a value greater than 0.70 showed good reliability for newly developed constructs. Measurement scales for all constructs were greater than 0.70 , which means all of them had adequate reliability (see Table 7 and 8 ). The results show that composite reliability values for all constructs are greater than 0.70 , which indicate good internal consistency (see Table 8 and 9)

Table 7: Construct Correlations, Discriminant Validity, and Reliability for quality factors and customer satisfaction conceptual model

\begin{tabular}{l|r|r|r|r|r|r|r}
\hline Constructs & \multicolumn{1}{l}{$\begin{array}{l}\text { Cronbach's } \\
\text { Alpha }\end{array}$} & $\begin{array}{l}\text { Composite } \\
\text { reliability }\end{array}$ & $\begin{array}{l}\text { Purchasing } \\
\text { experience }\end{array}$ & $\begin{array}{l}\text { Customer } \\
\text { Control }\end{array}$ & Reliability & Responsiveness & $\begin{array}{l}\text { Customer } \\
\text { Satisfaction }\end{array}$ \\
\hline $\begin{array}{l}\text { Purchasing } \\
\text { experience }\end{array}$ & 0.769 & 0.530 & 1 & 1 & & \\
\hline $\begin{array}{l}\text { Customer } \\
\text { Control }\end{array}$ & 0.775 & 0.782 & -0.007 & -0.006 & 1 & \\
\hline Reliability & 0.794 & 0.953 & 0.035 & -0.004 & 0.706 & \\
\hline Responsiveness & 0.659 & 1.117 & 0.025 & -0.034 & 0.172 & 1 \\
\hline $\begin{array}{l}\text { Customer } \\
\text { Satisfaction }\end{array}$ & 0.852 & 0.763 & 0.206 & 1 & 0.121 \\
\hline
\end{tabular}

Table 8: Construct Correlations, Discriminant Validity, and Reliability for logistics and quality factors on competitiveness model

\begin{tabular}{l|r|r|r|r|r|r}
\hline Constructs & \multicolumn{1}{l|}{$\begin{array}{l}\text { Cronbach's } \\
\text { Alpha }\end{array}$} & $\begin{array}{l}\text { Composite } \\
\text { reliability }\end{array}$ & $\begin{array}{l}\text { Purchasing } \\
\text { experience }\end{array}$ & $\begin{array}{l}\text { Logistics } \\
\text { Selection }\end{array}$ & Competitiveness & Reliability \\
\hline Purchasing experience & 0.793 & 0.530 & 1 & & \\
\hline Logistics Selection & 0.865 & 0.782 & 0.193 & 0.273 & 0.707 & \\
\hline Competitiveness & 0.739 & 0.953 & -0.211 & -0.195 & 1 & \\
\hline Reliability & 0.888 & 1.117 & -0.276 & 1 \\
\hline
\end{tabular}




\subsubsection{Testing of structural equation models}

We tested the proposed two structural equation models and the fit indices of them are shown in Table 9. Chi-square, comparative fit index, incremental fit index and root mean square error of approximation are within the suggested cut-off as shown in table 10.

Table 9: Fit indices for two different models

\begin{tabular}{llllll}
\hline & $x^{2}(\mathrm{df})$ & Normed $x^{2}$ & CFI & $\begin{array}{l}\text { RMSEA(\% } \\
\text { CI })\end{array}$ & IFI \\
\hline Model 1 & $49.405(35)$ & 1.412 & 0.974 & 0.050 & 0.974 \\
Model 2 & $160.363(104)$ & 1.542 & 0.883 & 0.092 & 0.887 \\
\hline
\end{tabular}

Table 10: Description of Fit indices (Source: Shah and Goldstein, 2006)

\begin{tabular}{lll}
\hline Fit index & Description & Suggested cut-off \\
\hline$x^{2} / d f$ & Normed chi-square: chi-square divided by degree of freedom & $(0.002,4.80)$ \\
CFI & $\begin{array}{l}\text { Comparative fix index: compares the model fit with a baseline } \\
\text { model }\end{array}$ & $(0.88,1.00)$ \\
IFI & $\begin{array}{l}\text { Incremental fit index: group of goodness of fit indices that } \\
\text { assesses how well a specified model fits relative to some }\end{array}$ & $(0.88,0.98)$ \\
& $\begin{array}{l}\text { alternative baseline model } \\
\text { RMSEA }\end{array}$ & \\
\hline
\end{tabular}

Fig. 3 shows the AMOS result of the structural equation model on customer satisfaction. Both $\mathrm{H} 1$ and $\mathrm{H} 2$ are supported by our set of data. Both e-service quality and service quality are positively related to customer satisfaction. The coefficient between e-service quality and customer satisfaction is significant with a value of $0.92(\mathrm{p}<0.001)$. It means that high eservice quality is strongly associated with high customer's satisfaction. The coefficient between service quality and customer satisfaction is also significant with a value of 0.17 $(\mathrm{p}<0.01)$. This means that high service quality is also associated with high customer's satisfaction. Moreover, the second-order latent variable model indicates that e-service quality is constructed only by purchasing experience (with a coefficient value of 0.22 and $p<0.001$ ). Customer control was not supported to formulate e-service quality, with a coefficient value of -0.04. As for the service quality, both reliability and responsibility are supported to forming the e-service quality (coefficient value of 0.99 and 0.71 respectively). 


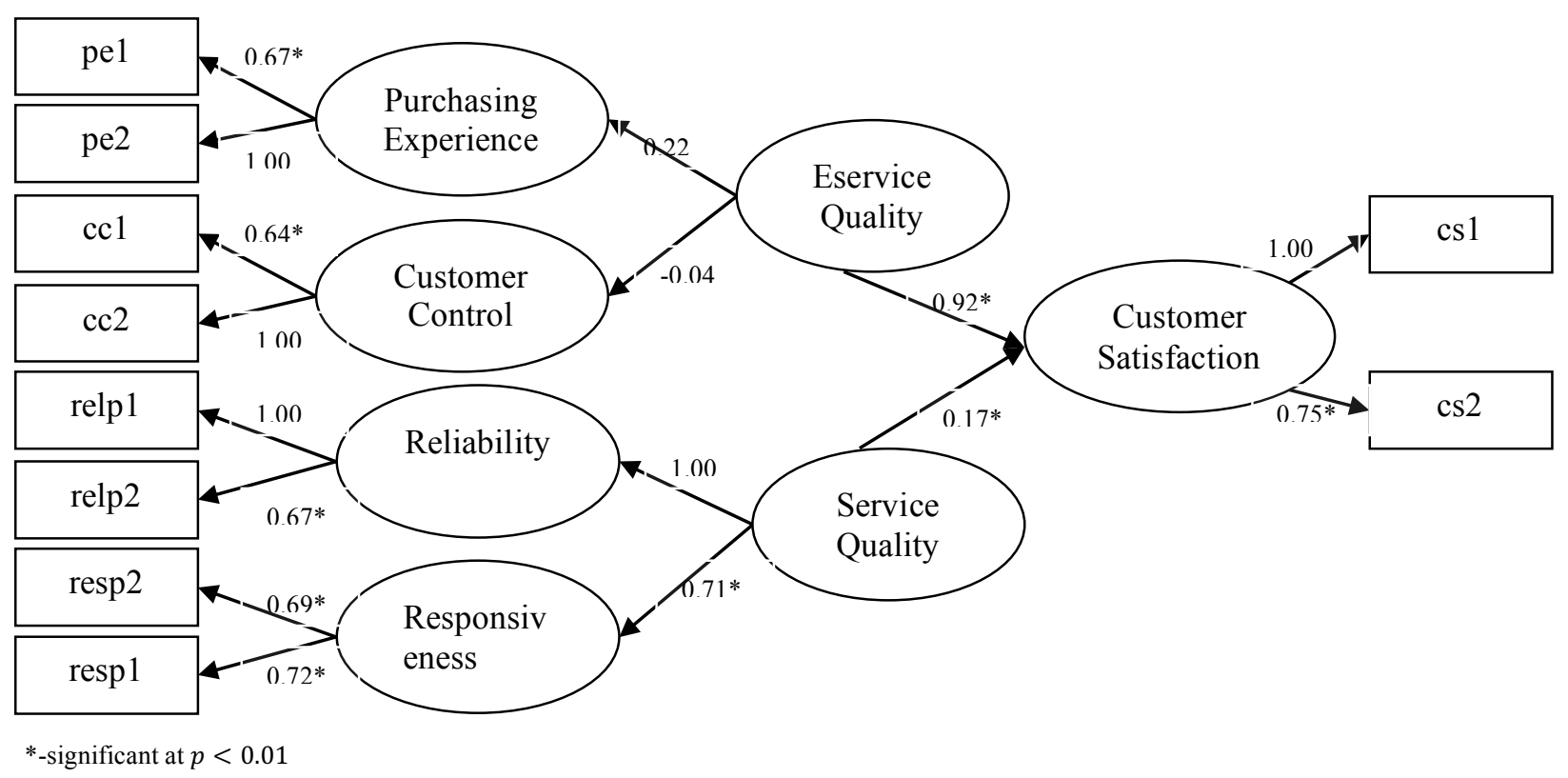

Figure 3: Results of structural equation model on customer satisfaction

Fig. 4 shows the AMOS result of the structural equation model of competitiveness. Both $\mathrm{H} 3$ and $\mathrm{H} 4$ are supported. The coefficient between logistics selection and competitiveness is significant with a value of $0.71(\mathrm{p}<0.001)$. This indicates that logistics options provided by the e-retailer and the choice of customer have more influence on the competitiveness of the Chinese e-retailer. Similarly co-efficient between quality and competitiveness is also found to be significant with a value of $0.6(\mathrm{p}<0.001)$. In the case of second order latent variable purchasing experience directly dominates $(0.46$ with $\mathrm{p}<0.001)$ the construction of quality factors whereas reliability indirectly dominates $(-0.46$ with $p<0.001)$ the quality constructs. The second order latent variable results indicate reliability is important and the Chinese customers never agree to pay more or settle at higher level of reliability in order to increase quality. 


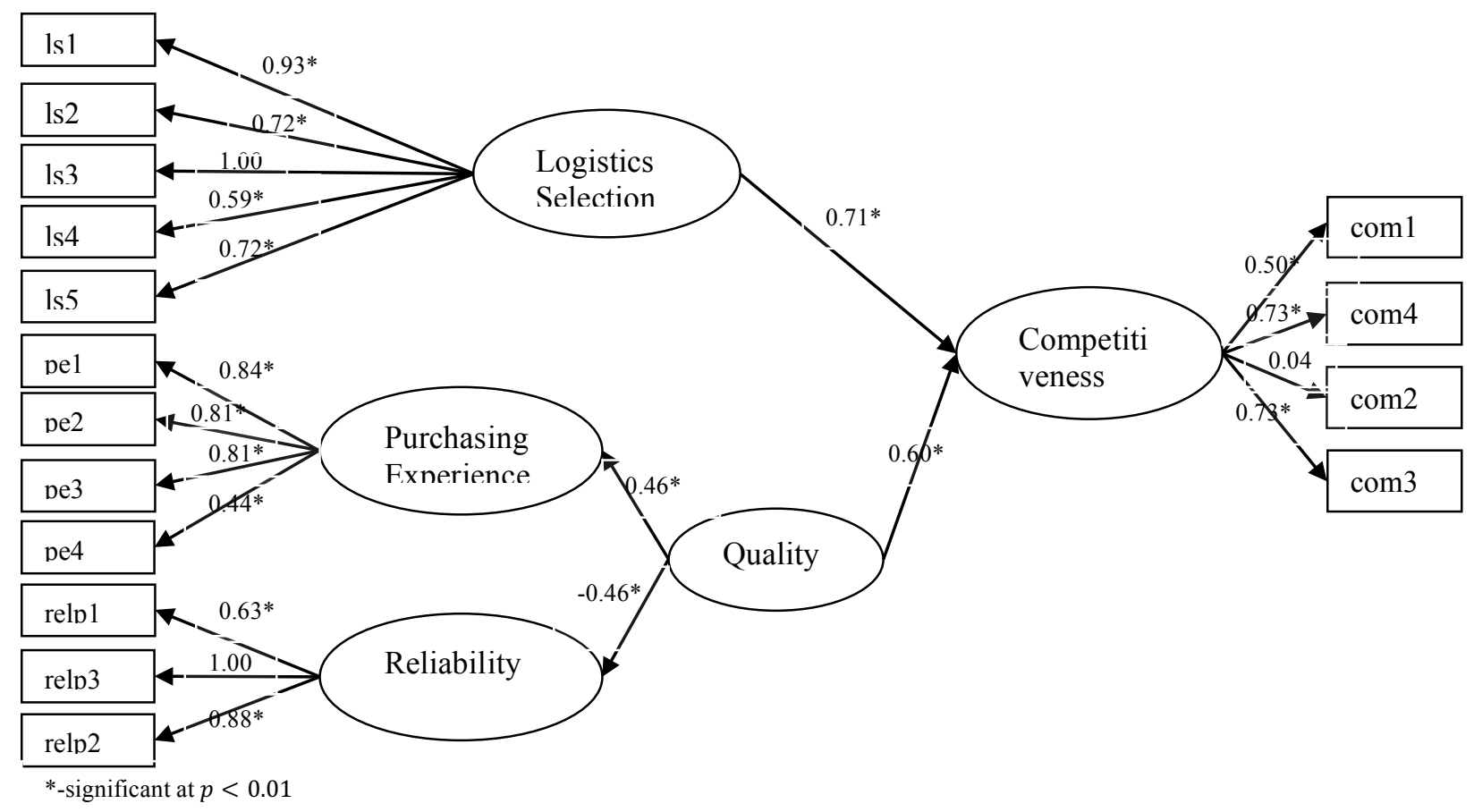

Figure 4: Results of the structural equation model on competitiveness

\section{Discussion}

\subsection{Customer satisfaction}

Our study and SEM analysis reveals that customer satisfaction of the products purchased through Chinese e-retailers is influenced by both service quality and e-service quality factors. Our findings are contrary to the previous study which identified service quality has no impact on customer satisfaction compared to information quality and system quality in web based customer support system( Joo and Sohn, 2008; Negash et al., 2003). In service quality we found both reliability and responsiveness are significant with respect to customer satisfaction. Our findings are in line with Selnes and Gonhaug (2000) argument that high reliability will have a strong positive effect on satisfaction. It is interesting to note that Chinese customers are paying more attention towards purchasing experience than customer control or price of the product. Since the Chinese online customers are consciousness towards price. Nowadays, Chinese customers expect core values, personalized care with improved products or service value rather than price to buy products through e-retailers. This finding is along the lines of previous study conducted by Ueltschy et al. (2009) which states that Chinese consumers are more like those in the United States and Europe in terms of their customer satisfaction ratings; they let you know what is on their mind. Customer control didn't get much importance due to standard regulation imposed by government and existence of customer complaint mechanism. Our analysis reveals that in future e-retailers to gain market share has 
to focus more on both e-service and service quality factors such as purchasing experience, reliability and responsiveness which ultimately lead to improved customer satisfaction.

\subsection{Competitiveness}

E-retailers are learning to meet customers' needs and provide high quality products and service. Customers demand more through online shopping and the products they buy depend on improved product varieties then they offer and additional services. It is obvious through our study that the tie-up the e-retailers going to have with the best logistics firms is a serious concern for their competitiveness. Because there were few reports which suggest that Chinese logistics operational efficiency is declining due to inadequate transportation and information technology infrastructures, local protection regulations and beaurocracy, shortage of quality logistics managers and lack of awareness of logistics concept (Zhou et al., 2008; Lau and Zhang, 2006; Tian et al., 2010). Meanwhile, logistic service providers are trying to enhance their service coverage and service quality which makes e-retailers to improve their marketing skills. This improvement lead to more customer satisfaction and positive market share growths in the e-retailing industry. Furthermore from our analysis it is obvious that customers are more cautious in selecting logistics service providers with due importance towards quality and price which conveys to e-retailer to be competitive and to focus more on options available to customers to pick a popular logistics service providers

To sum up, e-retailers will provide more and more personalized care and increase the products or service value to customers during online purchase. In due course, Chinese online customers hope to gain more advantages from online purchasing in the coming years. When it becomes part of customers' lifestyle, more unique personal needs will arise. Therefore, the risk of online shopping can be reduced and this shows a positive way to the market growth in the future.

\section{Conclusion}

This study captures Chinese e-Retailing on both customer and e-retailer perspectives. The study proposes two structural equation models to capture the role of service quality, e-service quality and selection of logistics providers on customer satisfaction and e-retailers competitiveness. The study empirically validates the models using a representative Chinese sample of young population who are more active in online shopping. The major findings of the study are purchasing experience of e-service quality, reliability and responsiveness of 
service quality drives Chinese customer satisfaction. To be competitive Chinese e-retailers should have good connections with top logistics service providers. Selections of logistics providers have a significant impact on competitiveness along with quality factors such as purchasing experience and reliability. The study is more focused towards electronics products and the results may vary if we consider different products. Furthermore the results are biased towards young population who are the active online users and their views will not be similar to other age groups. The sample is dominated by representation from single Chinese province and likely the inference may not be similar to other provinces. Future research can take into account the limitations in terms of sample and product. In addition to that they can propose a combined single model which has both customer satisfaction and competitiveness perspectives and find the influence of factors other than logistics selection and quality.

\section{References}

Anderson, R., \& Srinivasan, S., (2003). E-satisfaction and e-loyalty: a contingency framework. Phychology and Marketing, 20(2), 123-138.

Anderson, J. C., \& Gerbing, D. W. (1988). Structural equation modelling in practice: A review and recommended two-step approach. Psychological Bulletin, 103(3), 411-423.

Armstrong, S.J., Overton, T.S., 1977. Estimating non response bias in mail surveys. Journal of Marketing Research, 14 (3), 396-402.

Bames, S., \& Vidgen, R., (2002). An integrative approach to the assessment of e-commerce quality.Journal of Electronic Commerce Research, 3, 114-127.

Berry, L., Parasuraman, A., \& Zeithaml, V., (1985).A conceptual model of service quality and its implications for future research. Journal of Marketing, 4(49),1-15.

Bureau of Transport and Communications Economics, (1994).International aviation trends and issues.Australian Government Publishing Service, Canberra.

Buzzell, R., \& Gale, B., (1987). Market share - a key to profitability. Harvard Business Review, 1(53),10-21.

Campbell, D.T., and Fiske, D.W. "Convergent and discriminant validation by the multitraitmultimethod matrix," Psychological Bulletin (56:2), 1959, pp. 81-105.

Chang, Y., \& Chang, Y. (2010). Does service recovery affect satisfaction and customer loyalty? An empirical study of airline services.Journal of Air Transport Management, 16, 340-342.

Chang, Y., \& Yeh, C., (2002). A survey analysis of service quality for domestic airlines.European Journal of Operational Research, 139, 166-177.

Chen, B., Chen, X., Li, B., He, Z., Cao, H., \& Cai, G. (2011). Reliability estimation for cutting tools based on logistic regression model using vibration signals. Mechanical Systems and Signal Processing, 25, 2526-2537. 
Chenet, P., Tynan, C., \& Money, A. (2000). The service performance gap: testing the redeveloped causal model. Europran Journal of Marketing, 34, 472-483.

Chen, M., Chang, K., Hsu, C., \& Yang, I. (2011).Understanding the relationship between service convenience and customer satisfaction in home delivery by Kano model. Asia pacific Journal of Marketing and Logistics, 23(3), 386-410.

Chin, W.W. "Issues and Opinion on Structural Equation Modeling," MIS Quarterly (22:1), 1998, pp. 7-16.

Chiu,shao., Cheng, C., Yen, T., \& Hu, H. (2011). Preliminary research on customer satisfaction models in Taiwan: a case study from the automobile industry. Expert System with Applications, 38, 9780-9787.

Chou, C., Liu, L., Huang, S., Yih, J., \& Han, T. (2011).An evaluation of airline service quality using the fuzzy weighted SERVQUAL method.Applied Soft Computing, 11, 2117-2128.

CNNIC (2012). CNNIC statistic report of the development of internet in China, available at: http://www.cnnic.net.cn.

Collier, J., \&Bienstock, C., (2003). A conceptual framework for measuring E-service Quality: in developments in marketing science. Academy of Marketing Science, 158-62.

David, M., (2007).Culture, context, and behavior.Journal of Personalit, 75, 1285-1320.

Deng, Z., Lu, Y., Wei, K., \& Zhang, J. (2010).An empirical study of mobile instant messages in China.International Journal of Information Management, 30, 289-300.

EMS (2009). Domestic express- express service for online business, http://www.ems.com.cn/products/eyb.html, (Last accessed on $31^{\text {st }}$ August 31 2009).

Fassnacht, M., \&Koese, I., (2006). Quality of the electronic services: Conceptualizing and testing a hierarchical model. Journal of Service Research, 19, 20-37.

Fizsimons, J., \& Fitzsimons, M., (2001).Service Management, $3^{\text {rd }}$, New York: Free Press.

Garver, M.S., \&Gagnon, G.B., (2002). Seven keys to improving customer satisfaction programs.Business Horizon, 45, 35-42.

Gefen, D., (2002). Customer loyalty in e-commerce.Journal of Association for Information Systems, 3(1), 27-51.

Geng, X., \&Chu,X. (2012). A new importance-performance analysis approach for customer satisfaction evaluation supporting PSS design.Expert Systems with Applications, 39, 14921502 .

Gentry, J.W., (1982).The impact of credit decisions on shopping behavior.Advances in Consumer Research, 19, 368-385.

Goh, M., \& Ling, C., (2003).Logistics development in China.International Journal of Physical Distribution \& Logistics Management, 33(10), 886-917.

Gommans, M., Krishnan, K., \&Scheffold, K., (2001). From brand loyalty to e-loyalty: a conceptual framework. Journal of Economic and Social Research, 3(1), 43-58.

Gong, B., Chen, X., \& Hu, C. (2012).Fuzzy entropy clustering approach to evaluate the 
reliability of emergency logistics system. Energy Procedia, 16, 278-283.

Goodman Report (2012). An e-retailing research report commissioned by Goodman Group. http://article.wn.com/view/2012/05/22/Goodman_Report Sees_Significant_Logistics_Opport unity from $\mathrm{t}$ a/ $\left(\right.$ Last accessed on $12^{\text {th }}$ October 2012)

Gronroos, C., (1984). A service quality model and its marketing implications.European Journal of Marketing, 18, 9-21.

Hair, J. F., Black, W., C., Barbin, B. J., Anderson, R. E., \& Tatham, R. L. (2006). Multivariate data analysis ( $6^{\text {th }}$ ed. $)$. New Jersey: Prentice-Hall.

Hansemark, O., \&Albinsson, M., (2004).Customer satisfaction and retention: the experiences of individual emplyees. Jounal of Managing service Quality, 14, 40-57.

Holloway, B., \& Beatty, S., (2003).Service failure in online retailing: a recovery opportunity. Journal of Service Research, 6, 92-105.

Hong, J., \& Liu, B., (2007). Logistics development in China: a provider perspective. Transportation Journal, 46(2), 55-65.

Imrie, B., Cadogan, J., \& McNaughton, R., (2002). The service quality construct on a global stage. Managing service Quality, 12(1), 10-18.

Jahng, J.J., Jain, H., \& Ramamurthy, L., (2000). Effective design of electronic commerce environment: a proposed theory of congruence and an illustration. IEEE, 30(4), 456-471.

Janda, S., Philip, J., Gwinner, K., (2002).Consumer perceptions of internet retail service quality. International Journal of Service Industry Management, 13, 412-31.

Jane, C. (2011). Performance evaluation of logistics systems under cost and reliability considerations.Transportation Research Part E, 47, 130-137.

Jarvenpaa, L.S., \& Todd, A. P., (1997).Consumer reactions to electronic shopping on the World Wide Web.Presented in Orlando, 245-248.

Johnston, R., \&heineke, J., (1998).Exploring the relationship between perception and performance: priorites for action.The Service Industries Journal, 18(1), 101-112.

Joo, Y.G. and Sohn, S.Y. (2008), Structural equation model for effective CRM of digital content industry, Expert systems with Applications, 34, 63-71.

Jun, M., Yang, Z., \& Kim, D., (2004). Customer perceptions of online retailing service quality and their satisfaction. International Journal of Quality \& Reliability Management, 21, 817-840.

Kim, S., \&Stoel, L., (2004). Apparel retailers: website quality dimensions and satisfaction. Journal of Retailing and Customer Services, 11, 87-109.

Kim, W., Ma, X., \& Kim, D. (2006).Determinants of Chinese hotel customers' e-satisfaction and purchase intentions.Tourism Management, 27, 890-900. 
Kim, K. J., Jeong, I. J., Park, J. C., Park, Y. J., Kim, C. G., \& Kim, T. H. (2007). The impact of network service performance on customer satisfaction and loyalty: high-speed internet service case in Korea. Expert Systems with Applications, 32(3), 822-831.

Kolar, J. (2010). Logistics activities in relation to tangible and intangible operations.NabreziLudvikaSvobody, 12, 29-34.

Koufaris, M., (2002).Applying the technology acceptance model and flow theory to on-line consumer behavior.Information System Research, 13, 205-223.

Kuei,C.H., (1998). Service quality. In: Madu, C. (Ed), handbook of total quality management. Kluwer academic publishers, New York, pp246-259.

Kuo, M. (2011).A novel interval-valued fuzzy MCDM method for improving airlines service quality in Chinese cross-strait airlines.Transportation Research Part E, 47, 1177-1193.

Kuo, Y., Chou, J., \& Sun, K. (2011). Elucidating how service quality constructs influence resident satisfaction with condominium management. Expert System with Applicants, 38, $5755-5763$.

Kuo, Y., Wu, C., \& Deng, W. (2009). The relationships among service quality, perceived value, customer satisfaction, and post-purchase intention in mobile value-added services.Computers in Human Behavior, 25, 887-896.

Lai, F., Hutchinson, J., Li, D., \&Bai, C. (2007).An empirical assessment and application of SERVQUAL in mainland China's mobile communications industry.International Journal Quality \& Reliability Management, 24, 244-262.

Lai, K.-h., and Wong, C.W.Y, 2012. Green logistics management and performance: some empirical evidence from Chinese manufacturing exports. Omega 40, 267-282.Langley, C., Dort, E., Rose, T., Topp, U., Allen, G., \& Sykes, S., (2006). Third-party logistics: results and findings of the $11^{\text {th }}$ annual study, available at: http;//3plstudy.com.

Lau, K.H. and Zhang, J. (2006), "Drivers and obstacles of outsourcing practices in China", International Journal of Physical Distribution \& Logistics Management, Vol. 36 No. 10, pp. 776-92.

Lee, G., \& Lim, H., (2005). Customer perceptions of e-service quality in online shopping.International Journal of Retail \& Distribution Management, 33, 161-176.

Lin, G., \& Sun, C. (2009). Factors influencing satisfaction and loyalty in online shopping: an integrated model. Online Information Review, 33(3), 458-475.

Liu, H., Li, J., \& Ge, Y. (2006).Design of customer satisfaction measurement index system of EMS service.The Journal of China Universities of Posts and Telecommunications, 13(1), 109-113.

Liu, X., He, M., Gao, F., \& Xie, P. (2008). An empirical study of online shopping customer satisfaction in China: a holistic perspective. International Journal of Retail \& Distribution Management, 36(11), 919-940.

Liu, X., Zeng, X., Xu, Y.,\&Koehl, L. (2008). A fuzzy model of customer satisfaction index in e-commerce.Mathematics and Computers in Simulation, 77,512-521. 
Li, Y., Tan, K., \& Xie, M., (2002).Measuring web-based service quality.Total Quality Management, 13, 685-700.

Lin, W. B. (2007). The exploration of customer satisfaction model from a comprehensive perspective. Expert Systems with Applications, 33(1), 110-121.

Lohse, G.L., \& Spiller, P., (1998). Electronic shopping: designing online stores with effective customer interfaces has a critical influence on traffic and scales. Communication of ACM, 41(7), 81-87.

Long, M., \&McMellon, C., (2004). Exploring the determinants of retail service quality on the internet.Journal of Services Marketing, 18, 78-90.

Lu, H. T., (2005). The behavior differences of Chinese consumers. Chinese social science press: Beijing.

Mckinney, V., Kanghyun, Y., \&Zehedi, F.M., (2002).The measurement of web-customer satisfaction: an expectation and disconfirmation approach. Information system research, 13, 296-315.

Negash, S., Ryan, T., \& Igbaria, M. (2003). Quality and effectiveness in Web-based customer support systems. Information and Management, 40(8), 757-768.

Nevin, J.R., \& Houston, M., (1980).Images as a component of attractiveness to intra-urban shopping areas.Journal of Retailing, 56, 77-93.

Nunally, J.C. Psychometric Theory, McGraw-Hill, New York, 1978.

Olive, R.L., (1980). A cognitive model of the antecedents and consequences of satisfaction decisions.Journal of Marketing Research, 17(4), 460-469.

Pakdil, F., \& Harwood, T.N., (2005). Patient satisfaction in a preoperative assessment clinic: an analysis using SERVQUAL dimensions. Total quality management and business excellence, 16, 15-31.

Parasuraman, A., Zeithaml, V., \& Berry, L., (1988).SERVQUAL: a multiple item scale for measuring consumer perceptions of service quality. Journal of Retailing, 64, 12-40.

Parasuraman, A., Zeithaml, V., \& Berry, L., (1994).Reassessment of expectation as a comparison standard in measuring service quality.Journal of Marketing, 58(1), 111-124.

Parasuraman, A., Zeithaml, V., \&Malhotra, A., (2005).E-S-QUAL: A multiple-item scale for assessing electronic service quality. Journal of service research, 7, 213-33.

Ramezeni, M., Bashiri, M., \&Moghaddam, R. (2012).A new multi-objective stochastic model for a forward/ reverse logistic network design with responsiveness and quality level. Applied Mathematical Modelling, 2,1-17.

Pont, M., \&McQuiken, L., (2005).An empirical investigation of customer satisfaction and loyalty across two divergent bank segments.Journal of Financial Services Marketing, 9(4),344-359.

Power, D., Sharafali, M., and Bhakoo,V., (2007). Adding value through outsourcing: contribution of 3PL services to customer performance. Management Research News, 30(3), $35-78$. 
Riel, V., Liljander, V., \&Jurriens, P., (2001). Exploring customer evaluations of e-service: a portal site.International journal of service industry management, 12(4), 359-77.

Selnes, F., \& Gønhaug, K. (2000). Effects of supplier reliability and benevolence in business marketing. Journal of Business Research, 49(3), 259-271.

Shankar, V., Amy, K., \& Rangaswamy, A., (2003). Customer satisfaction and loyalty in online and offline environments. International Journal of Research in Marketing, 20(2), 75-153.

Sharma, A., Grewal, D., \& Levy, M., (1995). The customer satisfaction/logistics interface. Journal of Business Logistics, 16, 1-21.

Sheng, T., \& Liu, C. (2010).An empirical study on the effect of e-service quality on online customer satisfaction and loyalty. Nankai Business Review International, 1(3), 273-283.

Shah, R and Goldstein,S.M. (2006), Use of structural equation modeling in operations management research: Looking back and forward. Journal of Operations Management, 24, $148-169$

Shin, S.Y., Moon,T.H, Sohn, S.Y (2009), structural equation model for effective CRM of information infrastructure industry in Korea. Expert systems with Applications, 36, 16951705 .

Song, H., Veen, R., Li, G., \& Chen, J. (2012).The Hong Kong tourist satisfaction index.Annals of Tourism Research, 39(1), 459-479.

Song, Y., \& Yan, Z. (2006). Customer satisfaction theory applied in the housing industry: an empirical study of low-priced housing in Beijing. Tsingua Science and Technology, 11(6), 667-674.

Szymanski, M. D., \&Hise, T. R., (2000).E-satisfaction: an initial examination. Journal of Retailing, 76(3), 309-322.

Tan, K., \&Pawitra, T., (2001).Intrgrating SERVQUAL and kano's model into QFD for service excellence development. Managing Service Quality, 11(6), 418-433.

Tian Y, Ellinger AE, \& Chen H (2010) Third-party logistics provider customer orientation and customer firm logistics improvement in China. International Journal of Physical Distribution \& Logistics Management 40(5):356-376.

Ueltschy LC, Laroche M, Zhang M, Cho H, \& Yingwei R (2009) Is there really an Asian connection? Professional service quality perceptions and customer satisfaction. Journal of Business Research 62(10):972-979.

Verhoef, P., \&Langerak, J.,(2001). Possible determinants of consumers' adoption of electronic grocery shopping in the Netherlands.Journal of Retailing and Consumer Services, $8,275-285$.

Wang, Q., lai, F., \& Zhao, X., (2008). The impact of information technology on the financial performance of third-party logistics firms in China. Supply Chain Management: An International Journal, 13(2), 50-98. 
Wang, X., Zhang, J., Gu, C., \& Zhen, F. (2009). Examining antecedents and consequences of tourist satisfaction: a structural modeling approach.Tsinghua Science and Technology, 17(18), 397-406.

Wolfinbarger, M., \&Gilly, M., (2003).EtailQ: dimensionalizing, measuring, and predicting Etail quality. Journal of Retailing, 79, 98-113.

Wu, C., \& Liang, R. (2009).Effect of experiential value on customer satisfaction with service encounters in luxury-hotel restaurants.International Journal of Hospitality Management, 28, 586-593.

Wu, J., \& Wang, Y. (2011). A 3PL enterprise customer satisfaction evaluation method based on soft sets. IEEE, 7, 1885-1888.

Yang, J., \&Peng, S. (2008). Development of a customer satisfaction evaluation model for construction project management. Building and Environment, 43, 458-468.

Yoo, B., \&Donthu, N., (2001). Developing a scale to measure the perceived quality of internet shopping site.Journal of Electronic Commerce, 2, 31-46.

Yoon, C. (2010). Antecedents of customer satisfaction with online banking in China: the effects of experience. Computers in Human Behavior, 26, 1296-1304.

Yuksel, A., \&Yuksel, F., (2002).Measurement of tourist satisfaction with restaurant services: a segment-based approach. Journal of Vacation Marketing, 9, 52-68.

Zeithaml, V.A.,Parasuraman, A.,\&Malhotra, A., (2002). Service quality delivery through websites. Journal of the Academy of Marketing Science, 30(4), 362-375.

Zhang, X., Prybutok, V., and Huang, A., (2006).An empirical study of factors affecting eservice satisfaction. Human Systems Management, 25(4), 279-91.

Zhao, L., Lu, Y., Zhang, L., \&Chau, P. (2012).Assessing the effects of service quality and justice on customer satisfaction and the continuance intention of mobile value-added services: an empirical test of a multidimensional model. Decision Support Systems, 52, 645-656.

Zhou, G., Min, H., Xu, C., \& Cao, Z., (2008). Evaluating the comparative efficiency of Chinese third-party logistics providers using data envelopment analysis. International Journal of Physical Distribution \& Logistics Management, 38(4), 79-112.

\section{Appendix: The questionnaire}

Evaluate each question in 1 to 5 scales.

Equality

Pe1 How do you feel about purchasing online: product introduction

Pe2How do you feel about purchasing online: compare e-retailers' information

Pe3 How do you feel about purchasing online: search goods' information

Pe4 How do you feel about purchasing online: sellers' attitude

Cc1 What do you think about contact with customer service centre?

Cc2In your opinion, do complaints is easy for you

Customer satisfaction

Cs1 What gives you satisfaction during online purchasing: delivery speed

Cs2 What gives you satisfaction during online purchasing: sellers attitudes

Cs3 What gives you satisfaction during online purchasing: quality 
Service quality

Relp1 logistics records accurately

Relp2 safety operation

Relp3 goods intact rate

Resp1 satisfy the requirement of customers

Resp2 error solving time

Logistic selection

Ls1 How about the service of your preferred logistics provider: pre-sale service quality

Ls2 How about the service of your preferred logistics provider:after-sale service quality

Ls3 How about the service of your preferred logistics provider: pick-up process

Ls4 How about the service of your preferred logistics provider: delivery process

Ls5 How about the service of your preferred logistics provider: complaints solving abilities

Purchasing experience

Pe1 How do you feel about purchasing online: product introduction

Pe2 How do you feel about purchasing online: compare e-retailers' information

Pe3 How do you feel about purchasing online: search goods' information

Pe4How do you feel about purchasing online: sellers' attitude

Competitive

Com 1 What is your preferred e-retailer competitive advantage: price

Com2What is your preferred e-retailer competitive advantage: quality

Com 3 What is your preferred e-retailer competitive advantage: quality

Com4 What is your preferred e-retailer competitive advantage: service attitude

Com5 What is your preferred e-retailer competitive advantage: reputation of the company 